\title{
Narrative to Investigate Language Skills of Preschool Children*
}

\author{
Pelin Pistav Akmese ${ }^{a, *}$, Serap Kanmazb
}

$\begin{array}{ll}\text { Received } & : 15 \text { April } 2021 \\ \text { Revised } & : \text { 25 June } 2021 \\ \text { Accepted } & : \text { 17 August } 2021 \\ \text { DOI } & : 10.26822 / \text { iejee.2021.225 }\end{array}$

This research was generated from the master thesis which the co-author completed in Ege University Institute of Health Sciences Audiology and Speech Disorders Program of Department of Otolaryngology

"Corresponding Author: Pelin Pistav Akmese, Department of Audiology, Faculty of Health Sciences, Ege University, Izmir, Turkey.

E-mail: pelin.pistav.akmese@ege.edu.tr ORCID: https://orcid.org/0000-00018269-3899

' Serap Kanmaz, Fisilti Hearing Aid Center, Mugla, Turkey. E-mail: serapkanmaz48@gmail.com

ORCID: https://orcid.org/0000-0002-5865-9356

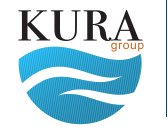

Copyright (c)

www.iejee.com

ISSN: 1307-9298

(C) 2021 Published by KURA Education \& Publishing. This is an open access article under the CC BYNC- ND license. (https://creativecommons.org/ licenses/by/4.0/)

\begin{abstract}
This study aimed to evaluate the language skills of preschool children through narrative. The Turkish Test of Early Language Development (TEDIL) was used to evaluate the receptive and expressive verbal language skills of the children, and language samples were collected using the Edmonton Narrative Norms Instrument (ENNI). The Mean Length of Utterance (MLU), Number of Different Words (NDW), and Total Number of Words (TNW) were examined in the language samples taken from the narrative analysis. A total of 100 children, 50 in the age group of 48-60 months and 50 in the age group of 61-72 months, were evaluated. According to the results obtained from the evaluation of the language skills of the children between the ages of 48 and 60 and 61 and 72 months, it was found that, children between the ages of 61-72 months were more likely to tell longer stories than the children of 48-60 months. It was seen that there were developmental differences in NDW and TNW in the stories of children between these two age groups. It has been revealed that the ENNI can be used as a language tool to assess the language skills in preschool children.
\end{abstract}

\section{Keywords:}

Preschool, Narrative, Language, Development

\section{Introduction}

hildren's language development improves in the first five years of life, starting from their first word until they form meaningful speech. Children often use narrative during the process of speaking to share their ideas and their experiences. Children's stories are important for determining language skills (Boudreau, 2008). Soares et al.(2010) reported that early storytelling in children develops with social and family interaction and early language acquisition in school, as well as during mother-child interaction.

Narrative skills show that a child can talk about his/her life beyond the use of grammar. Early narrative skills in children require a high level of language and cognitive skills. Stories are far more than the flow of unrelated words and sentences. Storytelling requires the use of complex and consistent linguistic structures. In order to create a coherent 


\section{iejee $\approx$}

linguistic structure, expressions that link the characters and events must be used in the narration (Paul \& Smith, 1993; Shiel et al., 2012; Uchikoshi et al., 2005). Complex syntactic structures and stories that elicit longer expressions are associated with comprehension skills, writing skills, and verbal language development. This provides a link between language and cognitive development. When cognitive development is considered to be the most basic tool for understanding the world, it is emphasized that acquiring narrative skills is not only a game for children, but also a means of expressing meanings that are inherent in life ( $\mathrm{O}^{\prime} \mathrm{Neill}$ et al., 2004; Stadler et al., 2005; Wagner et al., 2000).

Early narrative skills, including increased vocabulary, are associated with literacy skills such as using knowledge and clues, understanding the subject, morphological and syntactic skills, and various writing skills. Children's narrative skills advance them towards the process of oral literacy and prepare them for learning the written language, which is necessary for academic success. That is, stories support early literacy by creating a bridge between oral and written language (Çakıroğlu, 2019; Dickinson \& Smith, 1994; Hayward et al., 2009; Griffin et al., 2004; Westby et al., 1989).

In an examination of related literature, Stadler and Ward (2005) emphasized the importance of early storytelling by stating that stories require more complex language than daily language. Using appropriate words, pronouns, and conjunctions in the story increases the level of pre-reading language usage and facilitates the transition from spoken language to written language. Dickinson and Tabors (2002) also suggested that preschool story skills positively affect reading comprehension and receptive language in later periods. Another study by O'Neill et al. (2004) emphasized that the ability to produce stories in the early period can support mathematical skills.

Creating stories requires a high level of language use and cognitive skills. One should be able to plan what one has to say, sort thoughts, organize them in a meaningful way, and design the story with creative elements (Hegsted, 2013). Stories are one of the best ways to observe and evaluate children's pragmatic skills (appropriate language use in the context of verbal and non-verbal language) (Cummings, 2015). In addition to cognitive skills, storytelling at an early age is also related to socio-emotional development, including social cognitive skills such as bonding, emotional recognition, perspective, and awareness of the human mind and behavior (Schick \& Melzi, 2010). It was emphasized that early storytelling skills supported children's recall and planning skills in the future (Jack et al., 2009). Narrative skills not only enable children to convey the social messages of real and fictional events to others, but also enable them to form an oral meaning from their experiences. The language development of a small child includes the ability to narrate verbally. Lever and Senechal (2011) emphasized that it is important for children to learn the language as a whole in order to develop the ability to express abstract thoughts in their stories. The narrative is also an important result of early learning and positively affects the areas of social, emotional, and cognitive development (Shiel et al., 2012).

In studies on the development of storytelling, Soares et al. (2010) stated that two-year-old children were unable to use narration and only used time expressions in their vocabulary. At the age of three to four years, children used story patterns such as 'once upon a time" and "they lived happily ever after." Slobin (2004) found that although three-year-old children were able to form sentences, they were not successful in forming a story. Four-year-old children were able to narrate on the subject in accordance with given instructions, with storytelling forming a developmental transition for children between three and five years old. Munoz et al. (2003) reported that three and four-year-old children combined two or three events and had fewer stories compared to five-year-old children. Four-yearold children were able to tell meaningful stories but they could not form compatible sentences to form a full story. Five-year-old children were able to produce stories composed of interrelated sentences reflecting a consistent structure. Özcan (2005) emphasized that children between three and four years of age cannot produce stories; they use content outside of the plot that does not belong to the story. A consistent story is not observed until the age of five. Boudreau (2001) also suggested that five-year-old children could not produce regular stories following stage order. Similarly, Shapiro, and Hudson (1991) emphasized that the narrative skills of preschool children were weaker than those of primary school children. They stated that children under the age of six seem to have acquired the knowledge and skills necessary for story production, but cannot link events and characters without support. Once children are six years old, they can comprehend the sectional structures for story development and can make a consistent narrative. When the children reach the age of five to six, the problem of the subject and the solutions related to the subject show gradual development while forming the story, and children are able to tell more detailed stories (Kemper et al., 1995).

In another study conducted by Işıtan, and Turan (2014) showing that storytelling is gradual like language development, five basic periods are emphasized in the development of storytelling of preschool children. The children of three to four years of age were in the labeling period, and their stories had verbal labeling and included inconsistent repeating sentences; four year old children were in the period of the listing 
and they could list the status of the characters in the story and their stories were subject-centered; five year old children are in the period of connection, the connection can be seen between the sentences related to the subject center; The period between five to six was the ranking period and the children produced stories in a logical, hierarchical order and accordance with cause-effect relationship; It is stated that the six year period was narrative period and that the stories told by children include all the characteristics of the previous ages (Işıtan \& Turan, 2014).

Several studies showed that demographic features related to child and family affect the language development of the child (Gagne \& Crago, 2010; Lee, 2013; Reese \& Read, 2000; Saranlı et al., 2017; Schneider et al., 2006; Topbaş et al., 2004; Yıldız et al., 2009). In the studies conducted, it has been stated that being more open to stimuli after the age of two, when the language skills of children increase with their ages, and that the perception and attention are more intensely affected by language development (Reese \& Read, 2000; Topbaş et al., 2004). It has been also emphasized that as children grow up and environmental stimuli increase, language awareness, the number of words used, and language skills increase. Besides, it was stated that while children complete their language development stages with age, they learn to build meaningful sentences and understand the language they use. Thanks to the stimuli from the environment, they can establish logical relationships and make sense of the language they have started to speak (Şen et al., 2010). A study conducted by Saranlı et al. (2017) found that recipient language scores increase by age; recipient language scores of the 73 to 77 -month-old children are significantly higher than scores of 48 to 60-month-old-children, and scores of 61 to 72-monthold children are higher than the scores of 48 to 60-month-old children. In a study of Korean children, it was shown that children's ability to produce stories is an age-related developmental process (Lee, 2013). In addition, Işıtan and Turan (2014) emphasized that the age and gender-related differences in the storytelling skills of children with normal development can be seen in details

In studies that examined the relationship between gender and language development, Karmiloff and Karmiloff-Smith (2002) reported that cognitive development that was effective in language acquisition of girls occurred between 14 and 20 months, while this same change started in boys between the age of 20 and 24 months. They emphasized that the reason girls speak earlier than boys is that they have a wider vocabulary and speak more. In addition, it was stated that in the process of acquiring the mother tongue, girls performed at a higher level than boys in terms of speaking fluently, correctly in accordance with grammar rules, and with proper pronunciation. In another study, it was stated that girls who watch and imitate their mothers are able to speak better than boys in terms of the amount of speech, vocabulary, and proper formation of sentences (Tulu, 2009). Although some recent studies have concluded that there is no significant difference between girls and boys (Çiyiltepe, 2006; Erdoğan et al., 2005), others found that the language skills of gifted boys are better than those of girls (Saranlı et al., 2017).

Mother-child interaction and the quality of interaction in language development in the early childhood period contribute to language development in the following years. Longitudinal studies have proven that the sensitivity of mothers to interaction with the child's communication attempts has positive effects on language proficiency in the following years. The language used by the mother, the frequency of speaking with the child, and answering or asking questions is extremely important in language development. Some studies emphasized that mothers with low education and socioeconomic level use simpler language structures while talking with their children and do not use positive and supportive verbal communication (Baykan et al., 1995; Berkman, 1990). Schneider et al. (2006) also found that demographic characteristics such as the education level of the family affect language development. Furthermore, having an appropriate environment where children can learn and use language is closely related to language development. Erdoğan et al. (2005) claimed that the level of a mother's education does not affect the language development of five to six-year-old children who attend kindergarten, while the duration of attendance at nursery class or kindergarten is effective on the language development of children. In summary, the presence of a rich, stimulating environment in which a child experiences the language offered and there is a good model for using the language positively, supports the verbal communication of children.

\section{Language Evaluation and Narrative}

In recent years, storytelling has become a common feature of clinical evaluation and intervention. Storytelling analysis provides valuable insight into how children bring information together about language areas. Botting (2002) stated that the use of narration in language evaluation has three theoretical reasons: creating normative data, the relationship between narration and literacy, and dividing communication difficulties into different subgroups.

There are many language tests that evaluate words and sentences alone in the literature and clinical practices. Through storytelling, the child evaluates all aspects of receptive and expressive language. When 


\section{iejee}

creating stories that require high-level language use, children should use words and sentences in accordance with their purpose. It was emphasized that being a good narrator is an important skill in the life of young children. The stories that we learn about verbal language skills also facilitate the transition to reading and writing. Thus, it is emphasized that storytelling supports the academic achievement of school-age children (Schneider et al., 2006). The study of McCabe (1994) on the importance of storytelling development in the preschool period, suggested that creating a coherent story in terms of meaning positively affected the adaptation period to school and literacy skills. He also emphasized the importance of evaluating the narrative skills of preschool children in identifying children at risk for learning and literacy difficulties.

Storytelling skills are very important in preschool education, being widely applied in daily activities of the early age period. In this period, the storytelling is peculiar to the child and the fictional feature of the stories can also be observed. Such imaginary stories reflect the creativity of the child (Pistav Akmese, 2015). At the same time, as the stories have the developmental characteristics of the children, the levels of development can be compared thanks to the normative information. Thanks to the determination of the story development of the children with normal development, language problems in children can be identified and corrected in this early period. In addition, as the ability to tell stories predicts literacy skills, intervention programs for early storytelling skills positively affect advanced academic skills. Therefore, it is important to evaluate native language-specific storytelling skills in children with normal development. The aim of this study is to evaluate the language skills of children with normal hearing whose mother tongue is Turkish in the preschool period (48-60 months and 6172 months) through narration. Within this context, the research questions of the study are as follows:

1. Do the results of preschool children's receptive language, expressive language, verbal language scores, and MLU, NDW, and TNW differ according to the age groups of the children?

2. Do the results of preschool children's receptive language, expressive language, verbal language scores, and MLU, NDW, and TNW differ by gender?

3. Do the results of preschool children's receptive language, expressive language, verbal language scores, and MLU, NDW, and TNW differ according to the level of maternal education?

4. Is there a relationship among preschool children's age, education of the mother, receptive language, expressive language, verbal language scores, and MLU, NDW, and TNW results?

\section{Method}

This study, which deals with the language development of preschool children, is a descriptive survey. MLU, NDW, and TNW, the three developmental features for language development, and the receptive language, expressive language, and verbal language scores of preschool children between 48 and 60 months of age and 61 and 72 months were studied.

The study consists of 100 children with normal hearing in the preschool period. Demographic information about the parents of the children included in the study is given in Table 1.

When the distribution of children in the study group by age is examined, the average age of 50 children between 48 and 60 months is $4.11 \pm .19$, the average age of the mothers is $35.9 \pm 4.60$, and the average age of the fathers is $38.6 \pm 4.99$. The average age of 50 children between 61 and 72 months is $5.14 \pm 0.25$, the average age of mothers is $35 \pm 4.59$, and the average age of fathers is $38.4 \pm 5.32$. Six $(12 \%)$ of the mothers of 48 to 60-month-old children who participated in the study had primary education, 18 (36\%) had high school education, and 26 (52\%) had university education.

\section{Table 1}

Demographic Information of the Child and His Family (N:100)

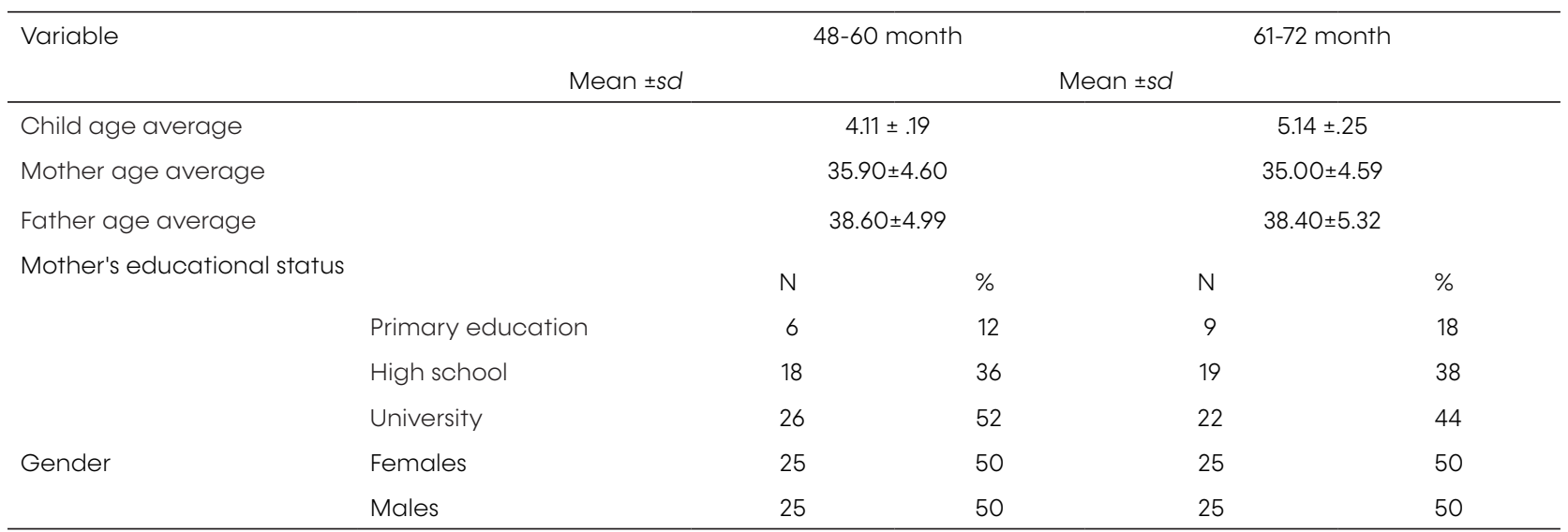


Nine $(18 \%)$ of the mothers of the children between 61 and 72 months are primary school graduates, 19 (38\%) are high school graduates, and 22 (44\%) are university graduates. One hundred children were included in the study: 25 boys and 25 girls in the 48 to 60 -month age group, 25 boys and 25 girls in the 61 to 72 -month group.

\section{Data Collection Tools}

The demographic information form containing information about the characteristics of children and their families, the Turkish Test of Early Language Development (TEDIL) to evaluate the receptive language, expressive language, and verbal language scores of children with normal hearing in the preschool period, and the Edmonton Narrative Norms Instrument (ENNI) storytelling tool to identify MLU, NDW, and TNW among language skills were used in the study.

\section{Demographic form}

The demographic information form is a form containing demographic information about the children in the study group and their families, such as children's age, gender, and mothers' educational level.

\section{Turkish Test of Early Language Development (TEDIL)}

Turkish Test of Early Language Development is applied to children aged 2;0 and 7;11. It is used to evaluate the receptive and expressive language of children whose mother tongue is Turkish. When the test is applied, the child's appropriate response to the items is marked as one point, and when it is not appropriate it is marked as zero points. The raw score is obtained with the total score that occurs. The raw score is then converted into standard language scores. The compound score obtained provides information about the child's general verbal language (Topbaş \& Güven, 2013).

\section{The Edmonton Narrative Norms Instrument (ENNI)}

The narrative skills assessment test ENNI is a tool that evaluates the language skills of four to nine-year-old children through narration. A training story consists of two sets of co-stories, A and B story sets. In this study, the A story set was used. The story shown to the children moves from simple pictures with two animal characters to a complex story with four characters. It was developed by Schneider et al. (2005) and it is a norm-based test. The stories used start with an educational story that prepares children to narrate. This story, which consists of five pictures, two characters, and an event, is applied to the child together with the researcher. Then, in order to motivate the child, we say "Now I'm turning this story to you and I can't see, can you tell me what's going on there? I am listening to you carefully." We pass to the A1, A2, and A3 stories, respectively. In order to indicate that the researcher is listening carefully, the researcher says "uh-huh", "continue", and "very well" between the pages to guide the child without affecting the story. Stories are recorded with a voice recorder. The records obtained are analyzed using the language sample program.

\section{Data Collection}

After the parental consent form was signed by the parents of the children participating in the study, the demographic information form containing general information about the children participating in the study and their families was filled out. Later, in order to evaluate the children's receptive language and Expressive Language Scores skills, the TEDIL and ENNI were applied in two sessions of 15-20 minutes as an individual interview with the child.

\section{Data Analysis}

Sound recordings obtained from TEDIL and ENNI were analyzed with the Systematic Analysis of Language Transcripts (SALT) language sample analysis program. The quantitative data obtained were analyzed using the SPSS 25.0 program. After the data were found to be normally distributed, general information was given using descriptive statistics. The t-test was used to detect the differences between MLU, NDW, TNW, and TEDIL tests obtained from ENNI by age and gender. The difference between TEDIL and ENNI, MLU, NDW, and TNW was analyzed by one-way analysis of variance (ANOVA). Pearson correlation analysis was performed for the relationship between the age of the child, TEDIL scores and the MLU, NDW, and TNW scores obtained from ENNI, and the level of maternal education.

\section{Results}

In the findings of the study, in which the study aimed to evaluate the language skills of preschool children through narration, the age and gender of children, the relationship between the variables of receptive language, expressive language, verbal language scores, and story development according to the level of maternal education were discussed. In the following section, the findings of the research are given according to the research questions.

1- Do the results of preschool children's receptive language, expressive language, verbal language scores, and MLU, NDW, and TNW differ according to the age groups of the children?

Information on the comparison of TEDIL scores by the age of the research group is given in Table 2.

In Table 2, when the TEDIL scores of children are compared, the mean of 61 to 72 - month-old children is 


\section{iejee $\approx$}

higher in all three subtests compared to the average of 48 to 60- month-old children, but the difference causes a statistically significant difference between receptive language scores $(p<.05)$ and verbal language scores $(p<.05)$.

Information regarding the comparison of the age group and the storytelling scores are given in Table 3.

In Table 3, when the MLU, NDW, and TNW scores of $A 1, A 2$, and $A 3$ stories included in the A story set are examined according to the age groups of the children, the mean scores of A1 NDW and TNW, A2 NDW and TNW, and A3 NDW and TNW of children aged 61 to 72 months are found to be higher than 48 to 60-month-old children. When the two age groups were compared, there was a significant difference between NDW and TNW obtained from the stories of $A 1, A 2$, and $A 3$ of 48 to 60 and 61 to 72-month-old children $(p<.05)$.
2- Do preschool children's receptive language, expressive language, verbal language scores, and MLU, NDW, and TNW results differ by gender?

Information on the comparison of TEDIL scores by age groups and genders of the research group is given in Table 4.

In Table 4, when the TEDIL scores of the children were compared, the average of the girls was higher than that of the boys, but the difference between the scores of receptive language, expressive language, and verbal language scores was not statistically significant.

Information regarding the comparison of the storytelling scores of the children in the study group by age groups and genders is given in Table 5 and Table 6.

\section{Table 2}

The T-test Results of TEDIL Scores According to the Age of the Children in the Research Group

\begin{tabular}{|c|c|c|c|c|c|}
\hline TEDIL & Age & N & Mean & $s d$ & $p$ \\
\hline \multirow{2}{*}{ Receptive language scores } & $48-60 \mathrm{~m}$ & 50 & 98.82 & 9.08 & \multirow{2}{*}{$.009^{\prime}$} \\
\hline & $61-72 m$ & 50 & 103.46 & 8.24 & \\
\hline \multirow{2}{*}{ Expressive language scores } & $48-60 \mathrm{~m}$ & 50 & 97.02 & 6.63 & \multirow{2}{*}{.124} \\
\hline & $61-72 \mathrm{~m}$ & 50 & 99.34 & 8.24 & \\
\hline \multirow{2}{*}{ Verbal language scores } & $48-60 \mathrm{~m}$ & 50 & 97.56 & 7.76 & \multirow{2}{*}{.013} \\
\hline & $61-72 \mathrm{~m}$ & 50 & 101.64 & 8.34 & \\
\hline
\end{tabular}

\section{Table 3}

The T-test Results of the Ages of the Children in the Research Group and the A History Set MLU, NDW, and TNW Scores

\begin{tabular}{|c|c|c|c|c|c|}
\hline ENNI & Age & $N$ & Mean & sd & $p$ \\
\hline \multirow{2}{*}{ A1 MLU } & $48-60 \mathrm{~m}$ & 50 & 5.77 & 2.05 & \multirow{2}{*}{.187} \\
\hline & $61-72 \mathrm{~m}$ & 50 & 6.26 & 1.59 & \\
\hline \multirow{2}{*}{ A1 NDW } & $48-60 \mathrm{~m}$ & 50 & 28.14 & 10.60 & \multirow{2}{*}{$.003^{*}$} \\
\hline & $61-72 \mathrm{~m}$ & 50 & 33.70 & 7.30 & \\
\hline \multirow{2}{*}{ A1 TNW } & $48-60 \mathrm{~m}$ & 50 & 53.52 & 22.34 & \multirow{2}{*}{$.004^{*}$} \\
\hline & $61-72 \mathrm{~m}$ & 50 & 66.84 & 22.20 & \\
\hline \multirow{2}{*}{ A2 MLU } & $48-60 \mathrm{~m}$ & 50 & 6.31 & 2.20 & \multirow{2}{*}{.157} \\
\hline & $61-72 \mathrm{~m}$ & 50 & 6.86 & 1.67 & \\
\hline \multirow{2}{*}{ A2 NDW } & $48-60 \mathrm{~m}$ & 50 & 43.28 & 14.26 & \multirow{2}{*}{$.000^{*}$} \\
\hline & $61-72 \mathrm{~m}$ & 50 & 52.18 & 9.83 & \\
\hline \multirow{2}{*}{ A2 TNW } & $48-60 \mathrm{~m}$ & 50 & 79.58 & 36.14 & \multirow{2}{*}{$.002^{*}$} \\
\hline & $61-72 \mathrm{~m}$ & 50 & 101.50 & 31.82 & \\
\hline \multirow{2}{*}{ A3 MLU } & $48-60 \mathrm{~m}$ & 50 & 6.33 & 2.19 & \multirow{2}{*}{.141} \\
\hline & $61-72 \mathrm{~m}$ & 50 & 6.90 & 1.59 & \\
\hline \multirow{2}{*}{ A3 NDW } & $48-60 \mathrm{~m}$ & 50 & 55.64 & 18.12 & \multirow{2}{*}{$.047^{*}$} \\
\hline & $61-72 \mathrm{~m}$ & 50 & 62.18 & 14.04 & \\
\hline \multirow{2}{*}{ A3 TNW } & $48-60 \mathrm{~m}$ & 50 & 127.28 & 49.91 & \multirow{2}{*}{$.002^{*}$} \\
\hline & $61-72 \mathrm{~m}$ & 50 & 161.86 & 58.17 & \\
\hline
\end{tabular}


In Table 5, when the MLU, NDW, and TNW scores of A1 and $A 2$ stories in the A group set of 48 to 60 -monthold children were examined according to age, it was observed that the mean scores of A1 MLU, A2 MLU, and A3 NDW of 48 to 60-month-old girls was higher than that of boys and the difference was statistically significant in favor of girls $(p<.05)$.

When $A 1, A 2$, and $A 3$ MLU, NDW, and TNW scores in the A history set of 61 to 72 -month-old children in the study group were examined according to gender in Table 6, it was found that the mean of A1 NDW, A2 NDW, A3 $\mathrm{MLU}$, and A3 NDW girls were higher than boys, and the difference was statistically significant in favor of girls $(p<.05)$.
3- Do the results of preschool children's receptive language, expressive language, verbal language scores, and MLU, NDW, and TNW differ according to the educational level of the mother?

Information on comparison of receptive language, expressive language, and verbal language scores according to the educational level of the mother of the children in the study group is given in Table 7.

When Table 7 is examined, no statistically significant difference was found between the mothers' educational level (primary, high school, university) and TEDIL receptive language, expressive language, and verbal language scores ( $p>.05)$.

\section{Table 4}

The T-test Results of TEDIL Scores According to the Gender of the Children in the Study Group

\begin{tabular}{|c|c|c|c|c|c|c|}
\hline Age & & TEDIL & $N$ & Mean & sd & $p$ \\
\hline \multirow{6}{*}{$48-60 \mathrm{~m}$} & \multirow[t]{2}{*}{ Receptive language scores } & Females & 25 & 105.36 & 8.23 & \multirow{2}{*}{.104} \\
\hline & & Males & 25 & 101.56 & 7.97 & \\
\hline & \multirow[t]{2}{*}{ Expressive language scores } & Females & 25 & 100.40 & 9.24 & \multirow{2}{*}{.369} \\
\hline & & Males & 25 & 98.28 & 7.20 & \\
\hline & \multirow[t]{2}{*}{ Verbal language scores } & Females & 25 & 103.36 & 9.16 & \multirow{2}{*}{.147} \\
\hline & & Males & 25 & 99.92 & 7.22 & \\
\hline \multirow{6}{*}{$61-72 \mathrm{~m}$} & \multirow[t]{2}{*}{ Receptive language scores } & Females & 25 & 100.96 & 9.32 & \multirow{2}{*}{.096} \\
\hline & & Males & 25 & 96.68 & 8.49 & \\
\hline & \multirow[t]{2}{*}{ Expressive language scores } & Females & 25 & 97.84 & 6.64 & \multirow{2}{*}{.388} \\
\hline & & Males & 25 & 96.20 & 6.67 & \\
\hline & \multirow[t]{2}{*}{ Verbal language scores } & Females & 25 & 99.32 & 7.59 & \multirow{2}{*}{.109} \\
\hline & & Males & 25 & 95.80 & 7.68 & \\
\hline
\end{tabular}

Table 5

The T-test Results of MLU, NDW, and TNW Scores According to the Gender of 48 to 60 -Month-Old Children in the Study Group

\begin{tabular}{|c|c|c|c|c|c|}
\hline ENNI & & $N$ & Mean & sd & $p$ \\
\hline \multirow{2}{*}{ A1 MLU } & Females & 25 & 6.39 & 2.08 & \multirow{2}{*}{$.032^{*}$} \\
\hline & Males & 25 & 5.15 & 1.86 & \\
\hline \multirow{2}{*}{ A1 NDW } & Females & 25 & 30.84 & 9.68 & \multirow{2}{*}{.071} \\
\hline & Males & 25 & 25.44 & 10.98 & \\
\hline \multirow{2}{*}{ A1 TNW } & Females & 25 & 57.76 & 19.80 & \multirow{2}{*}{.182} \\
\hline & Males & 25 & 49.28 & 24.28 & \\
\hline \multirow{2}{*}{ A2 MLU } & Females & 25 & 6.92 & 2.35 & \multirow{2}{*}{$.049^{*}$} \\
\hline & Males & 25 & 5.69 & 1.91 & \\
\hline \multirow{2}{*}{ A2 NDW } & Females & 25 & 45.88 & 12.51 & \multirow{2}{*}{.201} \\
\hline & Males & 25 & 40.68 & 15.64 & \\
\hline \multirow{2}{*}{ A2 TNW } & Females & 25 & 85.04 & 31.56 & \multirow{2}{*}{.290} \\
\hline & Males & 25 & 74.12 & 40.10 & \\
\hline \multirow{2}{*}{ A3 MLU } & Females & 25 & 6.90 & 2.18 & \multirow{2}{*}{.066} \\
\hline & Males & 25 & 5.76 & 2.08 & \\
\hline \multirow{2}{*}{ A3 NDW } & Females & 25 & 60.68 & 17.34 & \multirow{2}{*}{$.048^{*}$} \\
\hline & Males & 25 & 50.60 & 17.81 & \\
\hline \multirow{2}{*}{ A3 TNW } & Females & 25 & 140.84 & 43.12 & \multirow{2}{*}{.054} \\
\hline & Males & 25 & 113.72 & 53.33 & \\
\hline
\end{tabular}




\section{iejee}

The information regarding the comparison of the storytelling scores of the children in the research group according to the educational level of the mother is given in Table 8.

When Table 8 is examined, the difference between the mothers' educational status (primary, high school, and university) and MLU, TNW, and TNW scores of A1, $A 2$, and $A 3$ stories was not statistically significant ( $p$ > $.05)$.

Correlation values of the children's age, educational level of the mothers, receptive language, expressive language, verbal language scores, correlation MLU, NDW, and TNW scores for A1, A2, and A3 stories are given in Table 9.
In Table 9, the relationship between age, mothers' educational level of the children in the research group, TEDIL, and the MLU, NDW, and TNW scores of the ENNI story set were examined.

A positive correlation was found between the educational status of the mother and receptive language scores $(r=.209, p<.005), \mathrm{A} 2 \mathrm{MLU}(r=.198$, $p<.005)$, and A3 NDW $(r=.198, p<.005)$. A positive correlation was found with expressive language scores $(r=.443, p<.005)$ and verbal language scores $(r=.871, p<.005)$. Expressive language scores were positively correlated with verbal language scores $(r=$ .824, $p<.005)$, and negative correlations with A1 NDW $(r=-.210, p<.005)$.

\section{Table 6}

The T-test Results of MLU, NDW, and TNW Scores According to the Gender of 61 to 72-Month-Old Children in the Study Group

\begin{tabular}{|c|c|c|c|c|c|}
\hline ENNI & & $N$ & Mean & $s d$ & $p$ \\
\hline \multirow{2}{*}{ A1 MLU } & Females & 25 & 6.39 & 1.59 & \multirow{2}{*}{.548} \\
\hline & Males & 25 & 6.12 & 1.61 & \\
\hline \multirow{2}{*}{ A1 NDW } & Females & 25 & 35.88 & 8.73 & \multirow{2}{*}{$.033^{\prime}$} \\
\hline & Males & 25 & 31.52 & 4.76 & \\
\hline \multirow{2}{*}{ A1 TNW } & Females & 25 & 70.28 & 22.55 & \multirow{2}{*}{.278} \\
\hline & Males & 25 & 63.40 & 21.75 & \\
\hline \multirow{2}{*}{ A2 MLU } & Females & 25 & 7.05 & 1.40 & \multirow{2}{*}{.43} \\
\hline & Males & 25 & 6.68 & 1.92 & \\
\hline \multirow{2}{*}{ A2 NDW } & Females & 25 & 55.04 & 9.87 & \multirow{2}{*}{$.038^{*}$} \\
\hline & Males & 25 & 49.32 & 9.10 & \\
\hline \multirow{2}{*}{ A2 TNW } & Females & 25 & 104.88 & 29.37 & \multirow{2}{*}{.458} \\
\hline & Males & 25 & 98.12 & 34.36 & \\
\hline \multirow{2}{*}{ A3 MLU } & Females & 25 & 7.35 & 1.68 & \multirow{2}{*}{$.043^{\prime}$} \\
\hline & Males & 25 & 6.45 & 1.38 & \\
\hline \multirow{2}{*}{ A3 NDW } & Females & 25 & 67.04 & 13.99 & \multirow{2}{*}{$.013^{\prime}$} \\
\hline & Males & 25 & 57.32 & 12.56 & \\
\hline \multirow{2}{*}{ A3 TNW } & Females & 25 & 174.44 & 52.87 & \multirow{2}{*}{.128} \\
\hline & Males & 25 & 149.28 & 61.51 & \\
\hline
\end{tabular}

\section{Table 7}

The One-Way Analysis of Variance (ANOVA) Results of the Children in the Research Group in Relation to the TEDIL Scores According to the Educational Level of the Mother

\begin{tabular}{|c|c|c|c|c|c|c|}
\hline TEDIL & & Sum of squares & $d f$ & Mean square & $F$ & $p$ \\
\hline \multirow{3}{*}{$\begin{array}{l}\text { Receptive lan- } \\
\text { guage scores }\end{array}$} & Between groups & 438.25 & 2 & 219.12 & \multirow{3}{*}{2.845} & \multirow{3}{*}{.063} \\
\hline & In-group & 7471.78 & 97 & 77.02 & & \\
\hline & Total & 7910.04 & 99 & & & \\
\hline \multirow{3}{*}{$\begin{array}{l}\text { Expressive lan- } \\
\text { guage scores }\end{array}$} & Between groups & 45.73 & 2 & 22.86 & \multirow{3}{*}{.398} & \multirow{3}{*}{.673} \\
\hline & In-group & 5577.02 & 97 & 57.49 & & \\
\hline & Total & 5622.76 & 99 & & & \\
\hline \multirow{3}{*}{$\begin{array}{l}\text { Verbal language } \\
\text { scores }\end{array}$} & Between groups & 262.47 & 2 & 131.23 & \multirow{3}{*}{1.954} & \multirow{3}{*}{.147} \\
\hline & In-group & 6515.52 & 97 & 67.17 & & \\
\hline & Total & 6778.00 & 99 & & & \\
\hline
\end{tabular}


Table 8

One-Way Analysis of Variance (ANOVA) Results of the Children in the Research Group in Relation to MLU, NDW, and TNW Scores According to the Educational Level of the Mother

\begin{tabular}{|c|c|c|c|c|c|c|}
\hline & & Sum of squares & $d f$ & Mean square & $F$ & $p$ \\
\hline & Between groups & 8.06 & 2 & 4.03 & 1.189 & .309 \\
\hline \multirow[t]{3}{*}{ A1 MLU } & In-group & 328.91 & 97 & 3.39 & & \\
\hline & Total & 336.98 & 99 & & & \\
\hline & Between groups & 221.32 & 2 & 110.66 & 1.237 & .295 \\
\hline \multirow[t]{3}{*}{ A1 NDW } & In-group & 8678.03 & 97 & 89.46 & & \\
\hline & Total & 8899.36 & 99 & & & \\
\hline & Between groups & 91.48 & 2 & 45.74 & .084 & .920 \\
\hline \multirow[t]{3}{*}{ A1 TNW } & In-group & 52963.27 & 97 & 546.01 & & \\
\hline & Total & 53054.76 & 99 & & & \\
\hline & Between groups & 17.03 & 2 & 8.51 & 2.248 & .111 \\
\hline \multirow[t]{3}{*}{ A2 MLU } & In-group & 367.39 & 97 & 3.78 & & \\
\hline & Total & 384.42 & 99 & & & \\
\hline & Between groups & 326.38 & 2 & 163.19 & .968 & .384 \\
\hline \multirow[t]{3}{*}{ A2 NDW } & In-group & 16359.32 & 97 & 168.65 & & \\
\hline & Total & 16685.71 & 99 & & & \\
\hline & Between groups & 526.25 & 2 & 263.12 & .204 & .816 \\
\hline \multirow[t]{3}{*}{ A2 TNW } & In-group & 125124.58 & 97 & 1289.94 & & \\
\hline & Total & 125650.84 & 99 & & & \\
\hline & Between groups & .79 & 2 & .39 & .105 & .900 \\
\hline \multirow[t]{3}{*}{ A3 MLU } & In-group & 367.13 & 97 & 3.78 & & \\
\hline & Total & 367.93 & 99 & & & \\
\hline & Between groups & 1089.26 & 2 & 544.63 & 2.051 & .134 \\
\hline \multirow[t]{3}{*}{ A3 NDW } & In-group & 25754.92 & 97 & 265.51 & & \\
\hline & Total & 26844.19 & 99 & & & \\
\hline & Between groups & 2825.08 & 2 & 1412.54 & .435 & .649 \\
\hline \multirow[t]{2}{*}{ A3 TNW } & In-group & 314979.42 & 97 & 3247.21 & & \\
\hline & Total & 317804.51 & 99 & & & \\
\hline
\end{tabular}

Table 9

Correlation Values of the Children's Age, Educational Level of the Mothers, Receptive Language, Expressive Language, Verbal Language Scores, Correlation MLU, NDW and TNW Scores for A1, A2, and A3 Stories

\begin{tabular}{|c|c|c|c|c|c|c|c|c|c|c|c|c|c|}
\hline Child's Age & 1 & & & & & & & & & & & & \\
\hline $\begin{array}{l}\text { Mother } \\
\text { education }\end{array}$ & .008 & 1 & & & & & & & & & & & \\
\hline $\begin{array}{l}\text { Receptive } \\
\text { language scores }\end{array}$ & $.293^{*}$ & $.209^{*}$ & 1 & & & & & & & & & & \\
\hline $\begin{array}{l}\text { Expressive } \\
\text { language scores }\end{array}$ & -.141 & .085 & $.443^{*}$ & 1 & & & & & & & & & \\
\hline $\begin{array}{l}\text { Verbal language } \\
\text { scores }\end{array}$ & $.260^{*}$ & .179 & $.871^{*}$ & $.824^{*}$ & 1 & & & & & & & & \\
\hline A1 MLU & $.223^{*}$ & .138 & .031 & -.032 & -.009 & 1 & & & & & & & \\
\hline A1 TNW & $.385^{*}$ & .157 & -.060 & $-.210^{*}$ & -.161 & $.592^{*}$ & 1 & & & & & & \\
\hline A1 NDW & $.372^{*}$ & .041 & -.073 & -.052 & -.082 & $.578^{*}$ & $.767^{*}$ & 1 & & & & & \\
\hline A2 MLU & $.269^{*}$ & $.198^{*}$ & -.048 & .011 & -.032 & $.724^{*}$ & $.542^{*}$ & $.522^{*}$ & 1 & & & & \\
\hline A2 TNW & $.416^{*}$ & .119 & -.091 & -.066 & -.097 & $.582^{*}$ & $.676^{*}$ & $.629^{*}$ & $.631^{*}$ & 1 & & & \\
\hline A2 NDW & $.351^{*}$ & .023 & -.099 & -.068 & -.104 & $.539^{*}$ & $.587^{*}$ & $.743^{*}$ & $.602^{*}$ & $.845^{*}$ & 1 & & \\
\hline A3 MLU & $.256^{*}$ & .044 & -.115 & -.119 & -.144 & $.666^{*}$ & $.584^{*}$ & $.528^{*}$ & $.755^{*}$ & $.572^{*}$ & $.559^{*}$ & 1 & \\
\hline A3 TNW & $.315^{*}$ & $.198^{*}$ & -.015 & -.041 & -.038 & $.563^{*}$ & $.741^{*}$ & $.625^{*}$ & $.560^{*}$ & $.808^{*}$ & $.649^{*}$ & $.610^{*}$ & 1 \\
\hline A3 NDW & $.378^{*}$ & .026 & -.129 & -.041 & -.108 & $.465^{*}$ & $.644^{*}$ & $.807^{*}$ & $.501^{*}$ & $.725^{*}$ & $.824^{*}$ & $.583^{*}$ & $.773^{*}$ \\
\hline
\end{tabular}




\section{Discussion}

The aim of this study was to evaluate the language skills of preschool children between the ages of 48 to 60 and 61 to 72 months through narration. In this study, preschool children's receptive language, expressive language, verbal language scores, and language skills through narration and the developmental criteria MLU, NDW, and TNW were evaluated. The relationship between receptive language, expressive language, verbal language scores, MLU, NDW, and TNW in these age periods and demographic characteristics such as children's age, gender, and educational status of the children were examined.

The study found that 61 to 72-month-old and 48 to 60-month-old children had significant differences between receptive language and verbal language scores and between NDW and TNW scores obtained from A1, A2, and A3 stories. According to gender, the difference between the averages of $A 1 \mathrm{MLU}, A 2 \mathrm{MLU}$, and $A 3$ NDW in children between 48 and 60 months and A1 NDW, A2 NDW, A3 MLU, and A3 NDW in children between 61 and 72 months of age were statistically significant in favor of girls. The difference between the educational level of the mother (primary school, high school, and university) and the mean scores of receptive language, expressive language, verbal language, and MLU, TNW, and TNW for A1, A2, and A3 stories was not statistically significant. In addition, a positive correlation was found between the age of the child and receptive language scores, verbal language scores, the MLU, NDW, and TNW scores obtained from the $A 1, A 2$, and $A 3$ stories. A positive correlation was also found between the educational status of the mother and receptive language scores, A2 MLU, and A3 NDW. There was a positive relationship between receptive language scores, expressive language scores, and verbal language scores. At the same time, there was a positive relationship between expressive language scores and verbal language scores, and a negative relationship with A1 NDW.

The relationship between age, educational level of the mother, receptive language, expressive language, verbal language scores, and MLU, NDW, and TNW will be discussed in accordance with the literature.

\section{Differences between language skills according to children's ages}

This study found that 61 to 72-month-old children had higher receptive language scores and verbal language scores than those of 48 to 60-month-old children, and the difference was significant concerning receptive language scores and verbal language scores. When we take into account the storytelling skills, the MLU, NDW, and TNWs obtained from ENNI of 61 to 72-monthold children are higher than those of 48 to 60-month- old children. Although the MLU difference in the groups is not statistically significant, the difference between NDW and TNW is statistically significant. In our study, it was observed that TNW increased with age and 61 to 72-month-old children had more vocabulary than those 48 to 60 months old. When we compared the NDW in children between 48 and 60 months and those between 61 and 72 months, it was found that children between 61 and 72 months of age have different words than children between 48 and 60 months. This study concluded that the NDW showed a developmental characteristic with age. Similar to this study's results, developmental traces that differ by age have also been reported in narrative studies with different cultures (Gagne \& Crago, 2010; Schneider et al., 2006). Munoz et al., (2003) stated that complex syntactic structures of children in the four and fiveyear age group indicate developmental change. Although the five-year olds' MLU is longer than that of the four-year olds, their stories are similar in length and their narratives do not differ. Shapiro and Hudson (1991) stated that preschool children have good storymaking abilities, but they are inadequate in the use of high-level structures.

\section{Gender-Based Differences in the Language Skills of the Children}

The findings of the study revealed that girls between the ages of 48-60 and 61-72 months had higher receptive language scores and verbal language scores than boys, but the difference was not statistically significant. When we take the storytelling skills into account according to gender, the children between the ages of 61 and 72 months have higher MLU, NDW, and TNW than those aged 48-60 months. In other words, narration increases with age. The difference between the $A 1, A 2 \mathrm{MLU}$, and $\mathrm{A} 3 \mathrm{NDW}$ averages of 48 to 60-month-old girls and A1, A2, A3, NDW, and A3 MLU of 61 to 72-month-old girls was found to be statistically significant. In this study, while there was no difference in the recipient and expressive language in age groups, it was concluded that the girls in both age groups received higher scores in their stories in terms of vocabulary. When the literature is analyzed, different study results regarding language skills by gender draw attention. The results generally state that girls' language development is more advanced than that of boys (Karacan, 2000; Karmiloff \& KarmiloffSmith, 2002; Tulu, 2009; Yıldız Bıçakçı \& Aral, 2009) or that there is no significant difference between the genders (Çiyiltepe, 2006; Erdoğan et al., 2005).

Pistav Akmese et al. (2019) suggested that in the typical age group of 61 -72 months, there was no significant relationship between genders with a test of early literacy subtests (receptive vocabulary knowledge, phonological awareness, the knowledge of alphabet, and listening comprehension). 


\section{Differences Between Language Skills of Children} According to the Level of Mother Education

In this study, the effect of mothers' educational levels on children's language skills was examined in both preschool groups between the ages of 48-60 and 61-72 months. According to the mother's educational level, it was found that there was no significant difference between the receptive and expressive and mean word length of the children, and the number of different and total words. Similar to this study, Erdogan et al. (2005) asserted that the scores they received from children's language tests did not differ according to the level of the mothers' education. Contrary to the results of the study conducted by Erdogan et al. (2005), studies have shown that demographic features affect language development of the child. One of these studies, conducted by Schneider et al. (2006), emphasized that demographic features such as the educational level of the family affect language development. Pistav Akmese et al. (2019) stated that there is a statistically significant relationship between hearing loss with early literacy subtests (receptive vocabulary knowledge and listening comprehension) and maternal education $(p<.05)$. It is thought that the difference between the studies in the literature and our study is due to the fact that a large majority of the mothers of the children in our sample group had high school or university education.

Relationship Between Children's Age, Maternal Educational Level, Receptive Language, Expressive Language, Verbal Language Scores, and MLU, NDW, and TNW

In this study, a positive relationship was found between age and receptive language scores and verbal language scores of children between $48-60$ and 6172 months. When the relationship of the storytelling scores with age was examined, it was seen that there was a positive relationship between MLU, NDW, and TNW of preschool children in this study. It has been concluded that MLU, which we consider as the ratio of morphemes to expressions, increased with age in preschool period. Similar to the results of the study, O'Neill et al. (2004) emphasized that MLU positively correlates with the age of the child. In another study, it was emphasized that clinical applications related to MLU may also be important in evaluating high-level structural skills and MLU language skills by emulation (Munoz et al., 2003). NDW, which evaluates the variety of word levels, and TNW, which reveals the child's ability to produce words, also increase with age. Similar to this study, a study with Korean children emphasized that the ability of children to produce stories is an agerelated developmental process (Lee, 2013). A positive correlation was found between mothers' educational level and TEDIL acceptor standard score, A2 MLU, and A3 NDW. In this study, there was no difference between the educational level of the mother and language skills, but receptive language scores, A2 MLU, and A3 NDW scores increased in these sections as the mothers' educational level increased. Different results can be obtained in studies that will be conducted with a larger sample in this regard.

As a result, it was observed that MLU, NDW, and TNW results in this study were more sensitive than word syntax analysis. In their study, Paul and Smith (1993) emphasized that the developmental differences of children's stories in this period generally reflect changes in the length of use of the language.

\section{Conclusions}

This study examined the language skills, receptive and expressive and verbal language scores, MLU, NDW, and TNW of children between 48-60 months and 61-72 months of age. In the results of this study, differences in the receptive and expressive language scores of the children in the preschool period and NDW and TNW scores in their narration were presented. There was no significant difference in MLU scores. It was found that 61 to 72 -month-old children use different word roots and their vocabulary is better than 48 to 60-month-old children. MLU, NDW, and TNW scores showed some statistical differences which are not clinically significant in 48 to 60 and 61 to 72 -month-old girls who participated in the study, where receptive and expressive language scores and MLU, NDW, and TNW scores were higher than those of boys, but the difference between receptive and expressive language scores was not significant. It was concluded that there were statistical differences in some areas but they did not provide a clinical significance In this study, it was found that family's education level did not make any difference in receptive and expressive language scores, MLU, NDW, and TNW language criteria. Furthermore, when its relationship was examined, it did not have sufficient effect on language scores. In this study group, a positive correlation was found between the age of the children and the language of receptive and expressive language, and MLU, NDW, and TNW. It was revealed that MLU, NDW, and TNW increased with age, and that the ability of storytelling in children in the preschool period has a developmental characteristic and can be used as a clinical tool by reflecting age characteristics.

\section{Suggestions}

- Narrative can be used as a clinical tool in the risk and disability groups for the evaluation of language skills in preschool children.

- It is emphasized in the literature that early language skills predict the success of the school period (Stadler \& Ward, 2005). They can also be used in school-age children to evaluate narrative language skills. 


\section{iejee}

- In this study, the stories of preschool children were examined at the word level. In this period, a wide range of research can be conducted by examining children's stories in terms of story grammar theory.

- Preschool plays an important role in the language development of children. Supporting storytelling and storytelling skills of children in preschool education will support their language development positively.

\section{Acknowledgements}

This research was carried out within the scope of from in Ege University Scientific Research Project (SGA20717).

A part of this article was presented as a verbal proceeding at 10th Audiology and Speech Disorders Congress, 25-27 December 2020.

\section{References}

Baykan, S., Temel, F.Z., Ömeroğlu, E., Bulduk, S., Ersoy, Ö. Avcl., N., \& Turla, A. (1995). Ankara'da farklı sosyoekonomik düzeydeki 0-6 yaş çocuklarının gelişim durumlarının incelenmesi üzerine bir araştırma. Milli Eğitim Bakanlığı Okul Öncesi Eğitimi Genel Müdürlüğü ve Gazi Üniversitesi Mesleki Eğitim Fakültesi.

Berkman, S. (1990). Erken çocuk eğitiminde farklı modeller seminer bildirileri. UNICEF.

Botting, N. (2002). Narrative as a tool for the assessment of linguistic and pragmatic impairments. Child Language Teaching and Therapy, 18(1), 1-21. https//doi.org/10.1191/0265659002ct224oa

Boudreau, D. (2001). The development of narrative abilities in children. Language Learning Language Learning and Education, 8(2), 2-7. https://doi.org/10.1044/Ile8.2.2

Boudreau, D. (2008). Narrative abilities: Advances in research and implications for clinical practice. Topics in Language Disorders, 28(2), 99-114. https://doi.org/10.1097/01.TLD.0000318932.08807. da

Cummings, L. (2015). Pragmatic disorders. Pragmatics and Society, 6(2), 1-17. https://doi.org/10.1075/ ps.6.2.09pet

Çakıroğlu, A. (2019). The language acquisition approaches and the development of literacy skills in children. International Electronic Journal of Elementary Education, 11(2), 201-206. https:// doi.org/10.26822/iejee.2019248600
Çiyiltepe, M. (2006). Dil ve konuşma gelişiminde sorunlara yol açan nedenler. In S. Topbaş (Ed.), Dil ve Kavram Gelişimi (pp.158- 189). Kök Yayıncilık.

Dickinson, D. K. \& Smith, M. W. (1994). Long-term effects of preschool teachers' book readings on low-income children's vocabulary and story comprehension. International Reading Association, 29(2), 104-122. https://doi. org $/ 10.2307 / 747807$

Dickinson, D. K., \& Tabors, P. O. (2002). Fostering language and literacy in classrooms and homes. YC Young Children, 57(2), 10-18.

Erdoğan, S., Bekir H. B., \& Aras Erdoğan, S. (2005). Alt sosyoekonomik bölgelerde ana sınıfına devam eden 5-6 yaş grubundaki çocukların dil gelişim düzeylerine bazı faktörlerin etkisinin incelenmesi. Çukurova Üniversitesi Sosyal Bilimler Enstitüsü Dergisi,14(1), 231-246.

Gagne, A., \& Crago, M. (2010). The use of the ENNI to assess story grammar competency of school-aged French speaking children with and without specific language impairment. Canadian Journal of Speech-Language Pathology and Audiology, 34(4), 231-245.

Griffin, T.M., Hemphill, L., Camp, L., \& Wolf D. P. (2004). Oral discourse in the preschool years and later literacy skills. First Language, 24(2), 123-147. https://doi.org/10.1177/0142723704042369

Hayward, D. V., Schneider, P., \& Gillam, R. B. (2009). Age and task-related effects on young children's understanding of a complex picture story. Alberta Journal of Educational Research 55(1), 54-72.

Hegsted, S. (2013). Narrative development in preschool and school-age children. Utah State University Undergraduate Honors Capstone Projects. https://digitalcommons.usu.edu/honors/140.

Işıtan, S., \& Turan, F. (2014). Çocuklarda dil gelişiminin değerlendirilmesinde bir anlatı analizi yaklaşımı olarak öykü anlatımı. Eğitim Bilimleri ve Uygulama, 13(25), 105-124.

Jack, F., Macdonald, S., Reese, E., \& Hayne, H. (2009). Maternal reminiscing style during early childhood predicts the age of adolescents' earliest memories. Child Development, 80(2), 496-505. https://doi.org/10.1111/j.14678624.2009.01274.x.

Karacan, E. (2000). Çocuklarda dil gelişimini etkileyen faktörler. Sürekli Tıp Eğitim Dergisi, 7, 254-258. 
Karmiloff, K., \& Karmiloff Smith, A. (2002). Pathway to language. Harvard University Press.

Kemper, S., Vandepute, D., Rice, K., Cheung, H., \& Gubarchuk, J. (1995). Speech adjustments to aging during a referential communication task. Journal of Language and Social Psychology, 14, 40-59. https://doi.org/10.1177/0261927X95141003

Lee, J. Y. (2013). The use of the ENNI to assess narrative abilities of young Korean children (Unpublished master thesis) University of Alberta.

Lever, R., \& Sénéchal, M. (2011). Discussing stories: On how a dialogic reading intervention improves kindergartners' oral narrative construction. Journal of Experimental Child Psychology, 108(1), 1-24. 10.1016/j.jecp.2010.07.002

McCabe, A., \& Rollins, P. R.(1994). Assessment of preschool narrative skills. American Journal of Speech Language Pathology, 3, 45-56. https:// doi.org/10.1044/1058-0360.0301.45

Munoz, M. L., Gillam, R. B., Pena, E. D., \& GulleyFaehnle, A. (2003). Measures of language development in fictional narratives of Latino children. Language, Speech, and Hearing Services in Schools, 34(4), 332-342. https://doi. org/10.1044/0161-1461(2003/027)

O’Neill, D. K., Pearce, M. J., \& Pick, J. L. (2004). Preschool children's narratives and performance on the peabody individualized achievement test revised: Evidence of a relation between early narrative and later mathematical ability. First Language, 24, 149-183. https://doi. org/10.1177/0142723704043529

Özcan, M. (2005). The emergence of temporalelements in narrative units produced by children from 3 to 9 plus 13 (Unpublished doctoral dissertation). Middle East Technical University.

Paul, R. \& Smith, R. L. (1993). Narrative skills in 4-year-olds with normal, impaired, and late- developing language. Journal of speech \& Hearing Research, 36(3), 592-598. https://doi.org/10.1044/ jshr.3603.592

Pistav Akmese, P. (2015). Çocuklarda öykülemenin gelişimi ve dilin değerlendirilmesinde kullanımı. Ankara Üniversitesi Eğitim Bilimleri Fakültesi Özel Eğitim Dergisi, 3(16), 293-305. https://doi. org/10.1501/Ozleg†_0000000233
Pistav Akmese, P., Sezgin, D., \& Öğüt, F. (2019). Investigation of early literacy skills in preschool children with deaf and hard of hearing. International Electronic Journal of Elementary Education, 12(2), 137-143. https://doi.org/10.26822/ iejee.2019257659

Reese, E., \& Read, S. (2000). Predictive validity of the New Zealand MacArthur communicative development inventory: Words and sentences. Journal of Child Language, 27(2), 255-66. https:// doi.org/10.1017/s0305000900004098.

Saranlı, A. G., Er, S., \& Deniz, K. Z. (2017). Okul öncesi dönemdeki üstü yetenekli çocukların dil gelişimlerinin analizi, Yaşadıkça Eğitim, 31(1), 1-20.

Shapiro, L. R. \& Hudson, J. A. (1991). Tell me a makebelieve story: Coherence and cohesion in young children's picture-elicited narratives. Developmental Psychology, 27(6), 960-974. https://doi.org/10.1037/0012-1649.27.6.960

Schick, A. \& Melzi, G. (2010). The Development of children's oral narratives across contexts. Early Education and Development, 21(3), 293-317. https://doi.org/10.1080/10409281003680578

Schneider, P., Dubé, R.V., \& Hayward, D. (2005). In The Edmonton Narrative Norms Instrument. http:// www.rehabresearch.ualberta.ca/enni/.

Schneider, P., Hayward, D., \& Dube, R. V. (2006). Storytelling from pictures using the Edmonton Narrative Norms Instrument. Journal of Speech Pathology and Audiology, 30(4), 224-238.

Shiel, G., Cregan, Á., McGough, A., \& Archer, P. (2012). Oral language in early childhood and primary education (3-8 years). National Council for Curriculum and Assessment. http://www. erc.ie/documents/oral_language_in_early childhood_and_primary_education_3-8_ years_pdf

Slobin, D. I. (2004). The many ways to search for a frog: Linguistic typology and the expression of motion events. In S. Strömqvist \& L. Verhoeven (Eds.), Relating Events in Narrative (pp. 219-257). Psychology Press.

Soares, A. D., Goulart, B. N. G., \& Chiari, B. M. (2010). Narrative competence among hearingimpaired and normal-hearing children: analytical cross-sectional study. Sao Paulo Medical Journal, 128(5), 284-288. https://doi. org/10.1111/1460-6984.12427 
Stadler, M. A. \& Ward, G. C. (2005). Supporting the narrative development of young children. Early Childhood Education Journal, 33(2),73-80. https://doi.org/10.1007/s10643-005-0024-4

Şen, S. Yıldız Çiçekler, C., \& Yılmaz, R. (2010). Okul öncesi eğitim kurumlarına devam eden ve etmeyen 56 yaş çocukların üstdil becerilerinin incelenmesi. Ondokuz Mayıs Üniversitesi Eğitim Fakültesi Dergisi, 29(2), 37-54.

Topbaş, S., Bestoy, U., Demirpehlivan, B., Sezer, E., Kılıç, M. A., \& Deniz, M. (2004). Gaziantep ilinde yaşayan 5:0-8:0 yaş çocuklarının dil gelişimlerinde sesbilgisel işlemlerin incelenmesi. 2. Ulusal Dil ve Konuşma Bozuklukları Kongresi Bildiri Kitabı. Kök Yayıncilık.

Topbaş, S., \& Güven, S., (2013). TEDIL-Türkçe Erken Dil Gelişim Testi (TELD-3: Test of Early Language Development-Third Edition: Turkish). Detay Yayıncilık.

Tulu, Y. (2009). Ana dili Türkçe olan ve ana dili Türkçe olmayan (iki dilli) 4-7 yaş çocukların dil düzeylerine etki eden faktörlerin incelenmesi (Yayınlanmamış yüksek lisans tezi). Selçuk Üniversitesi.

Uchikoshi, Y., Santos, C., Gomez, F., Keith, K., \& Jazo, E. (2005). Narrative development in bilingual kindergarteners: can Arthur help? Development Psychology, 41(3), 464-478. https://doi. org/10.1037/0012-1649.41.3.464.

Wagner, C. R., Nettelbladt, U., Sahlen, B., \& Nilholm, C. (2000). Conversation versus narration in preschool children with language impairment. International Journal of Language and Communication Disorders, 35(1), 83-93. https:// doi.org/10.1080/136828200247269.

Westby, C., Richard, V. D., \& Maggart, Z. (1989). Assessing narrative competence. Seminars in Speech and Language, 10(1), 63-76. https://doi. org/10.1055/s-0028-1082490

Yıldız Bıçakçı, M., \& Aral, N. (2009). Dil gelişimi. In N. Aral \& T Duman(Eds.), Eğitim Psikolojisi (pp.115-130). Kriter Kitabevi. 